Uwoh Saepuloh Penerapan Manajemen Teknik Informasi Pendidikan Islam Dalam Proses Pembelajaran Di Smk Harapan 1 Rancaekek Bandung

\title{
PENERAPAN MANAJEMEN TEKNIK INFORMASI PENDIDIKAN ISLAM DALAM PROSES PEMBELAJARAN DI SMK HARAPAN 1 RANCAEKEK BANDUNG
}

\author{
Uwoh Saepuloh \\ Mahasiswa Pascasarjana S3 UIN SGD Bandung \\ e-mail: uwohsaepulohfdk@gmail.com
}

\begin{abstract}
Tujuan penelitian ini untuk mengetahui penerapan manajemen teknik informasi pendidikan islam dalam proses pembelajaran di SMK Harapan 1 Rancaekek Bandung. Penelitian ini memakai pendekatan kualitatif dengan metode deskriptif Adapun hasil penelitian menunjukkan bahwa : 1) Penerapan sistem informasi manajemen sangat penting dilembaga pendidikan khusunya di SMK Harapan 1 Rancaekek Bandung menggunakan aplikasi pengolah data yaitu dapodik dan teknik informasi dalam mendukug proses pembelajaran memberikan layanan pendidikan dengan menfasilitasi praktek pembelajaran dengan menggunakan infrakstruktur teknologi, seperti fasilitas belajar dengan memadukan computer 2) Proses pembelajaran di sekolah ini yaitu, sebelum melaksanakan proses pembelajaran harus melalui tiga tahap yaitu, pertama, tahap perencanaan yang meliputi analisis hari efektif, analisis program pembelajaran, program tahunan, menyusun silabus, menyusun RPP, dan membuat penilaian pembelajaran . Kedua, tahap pelaksanaan, yang meliputi aspek pendekatan dalam pembelajaran, aspek stretegi dan taktik dalam pembelajaran, aspek metode dan teknik dalam pembelajaran. Ketiga, tahap evaluasi, dalam tahap ini yang dievaluasi yaitu, pengetahuan belajar yang dites dengan secara tertulis, lisan, dan daftar pertanyaan ujian.
\end{abstract}

Kata Kunci : manajemen, teknik informasi, pendidikan islam, proses pembelajaran

\section{Abstract}

The purpose of this study was to determine the application of management of Islamic education information techniques in the learning process at SMK Harapan 1 Rancaekek Bandung. This study uses a qualitative approach with descriptive methods. The results of the research show that: 1) The application of management information systems is very important in educational institutions, especially at SMK Harapan 1 Rancaekek Bandung using data processing applications, namely dapodics and information techniques in supporting the learning process to provide educational services by facilitating practice learning using technology infrastructure, such as learning facilities by integrating computers 2) The learning process in this school, namely, before carrying out the learning process must go through three stages, namely, first, the planning stage which includes analysis of effective days, analysis of learning programs, annual programs, compiling syllabus, compiling lesson plans, and making learning assessments. Second, the implementation stage, which includes aspects of the approach in learning, aspects of strategy and tactics in learning, aspects of methods and techniques in learning. Third, the evaluation stage, in this stage what is evaluated, namely, learning knowledge that is tested by writing, orally, and a list of exam questions.

Keywords: management, information engineering, Islamic education, learning process

\section{PENDAHULUAN}

Pengelolaan atau manajemen yang baik dalam suatu lembaga pendidikan menjadi hal yang mutlak bagi keberlangsungan hidup lembaga tersebut. Salah satu hal penting yang dapat mempertahankan bahkan mengembangkan sebuah lembaga pendidikan adalah pengelolaan teknik informasi secara 
tepat. Kemajuan ilmu dan teknik informasi telah banyak mengubah cara pandang dan gaya hidup masyarakat Indonesia dalam menjalankan kegiatannya, termasuk dalam dunia pendidikan Islam.

Peningkatan kinerja pendidikan di masa mendatang diperlukan sistem informasi dan teknik informasi yang tidak hanya berfungsi sebagai sarana pendukung, tetapi lebih sebagai senjata utama untuk mendukung keberhasilan dunia pendidikan sehingga mampu bersaing di pasar global. Sistem pendidikan telah berusaha untuk melakukan perubahan yang mendasar, misalnya melalui tiga bentuk kebijakan pemerintah. Pertama, meningkatkan ketentuan wajib belajar dari 6 ke 9 tahun. Kedua, mengarahkan pendidikan agar lebih relevan dengan perkembangan industri, dengan teknik informasi atau memiliki keterkaitan dan kesesuaian. Ketiga, mendorong pendidikan sekolah menengah untuk lebih banyak menyiapkan tenaga terampil sehingga lulusannya tidak memandang perguruan tinggi sebagai satusatunya alternatif pilihan masa depan .

Salah satu faktor dalam menciptakan lingkungan belajar yang kondusif dengan lingkungan pandang dan dengar (audiovisual) yang dalam hal ini dapat diciptakan dengan memanfaatkan teknologi informasi. Jadi, dapat diambil kesimpulan bahwasanya untuk mempermudah peserta didik dalam belajar, salah satunya dengan menggunakan media. Komponen utama yang dibutuhkan untuk menghasilkan sistem informasi manajemen pendidikan yang efektif dan berkualitas, yaitu tersediannya teknik informasi yang digunakan oleh sumber daya manusia yang mampu mengoperasikannya. Lingkungan internal maupun eksternal selalu berkembang dan bersifat dinamis sehingga menimbulkan kesempatan atau hambatan pertumbuhan bagi lembaga pendidikan. Penyebabnya adalah keputusan yang dibuat oleh pihak manajemen. Manajemen pendidikan mempunyai tugas membuat keputusan, tetapi tugas ini merupakan aspek krisis yang menuntut kemampuan manajerial untuk mengintegrasikan dan mengembangkan sebagai elemen yang relevan ke dalam situasi lembaga pendidikan secara keseluruhan.

Dalam menjalankan tugasnya pihak manajemen akan dihadapkan pada terbatasnya waktu, resiko yang mungkin mengancam stabilitas lembaga pendidikan dan keputusan yang diambil harus dikomunikasikan pada pihak pelaksana (petugas operasional), seperti pendidik dan tenaga pendidik. Untuk menghadapi hambatan maupun tantangan lingkungan dan kemampuan dalam membuat keputusan, pihak manajemen pendidikan memerlukan strategi yang tepat agar tujuan pendidikan dapat tercapai secara optimal. Pada umumnya, apabila seseorang membicarakan manajemen teknik informasi, yang tergambar adalah suatu sistem yang diciptakan untuk melaksanakan pengolahan data yang akan dimanfaatkan suatu organisasi. Pemanfaatan di sini dapat berarti penunjang pada tugas-tugas rutin, evaluasi terhadap prestasi organisasi, atau untuk pengambilan keputusan oleh organisasi tersebut. Kini kalau seseorang mendengar istilah manajemen teknik informasi, biasa juga mereka membayangkan suatu sistem komputer. Inti pengertian manajemen teknik informasi konvensional tentu saja terkandung dalam pekerjaan- pekerjaan sistematis seperti pencatatan agenda, kearsipan, komunikasi di antara manajer-manajer organisasi, penyajian informasi untuk pengambilan keputusan, dan lain sebagainya .

Di SMK Harapan 1 Rancaekek Bandung sebagai lembaga pendidikan formal yang menerapkan manajemen teknik informasi pendidikan, sebagai solusi dalam rangka menyikapi segala perubahan dan perkembangan yang terjadi di lingkungannya, khususnya di bidang pendidikan serta perannya dalam proses pembelajaran. Salah satu alasan diterapkan teknik informasi pendidikan di sekolah ini, yaitu untuk memperlancar proses belajar mengajar di sekolah, Karena dilihat dari kondisi penyediaan bahan ajar atau buku pelajaran sangatlah kurang, maka pendidik di SMK Harapan 1 Rancaekek Bandung memanfaatkan teknik informasi yang ada untuk senantiasa mengarahkan siswanya pada 
program-program dan kegiatan untuk mendapat bahan ajar dengan cara membuat program-program pendidikannya dengan memakai aplikasi pembelajaran yang berbasis IT serta pembelajaran online E-Learning. Seperti program al Qur'an flash, program al Qur'an in word, program penghitungan software zakat, software waris, software pemulasaraan jenazah dan program E-Book guna memperlancar proses belajar mengajar, dan data- data sekolah agar lebih mudah diakses.

Penerapan manajemen teknik informasi pendidikan adalah sebagai pendukung kegiatan fungsi manajemen seperti planning, organizing, actuating, controlling dalam rangka menunjang tercapainya sasaran dan tujuan fungsi-fungsi operasional dalam organisasi pendidikan. Mencermati berbagai fenomena dari perkembangan manajemen teknik informasi pendidikan dan pemanfaatannya di dalam dunia pendidikan saat ini maka bagaimana seharusnya pihakpihak terkait mengantisipasi perkembangan manajemen teknik informasi pendidikan serta pemanfaatannya tanpa kehilangan kontrol dan landasan organisasi pendidikan yang antara lain menyangkut efektivitas dan efisiensinya.

\section{METODOLOGI}

Pendekatan dalam penelitian ini yaitu kualitatif, dengan metode deskriptif analitik. Objek penelitian dilakukan pada para stake holder kepala sekolah, guru dan siswa di SMK Harapan 1 Rancaekek Bandung. Teknik pengumpulan data dengan wawancara, observasi, dan dokumentasi. Sedangkan analisis datanya melalui reduksi data, display data, dan penarikan kesimpulan.

\section{HASIL DAN PEMBAHASAN}

1. Kajian tentang manajemen Teknik informasi pendidikan Islam

1) Definisi Manajemen Teknik Informasi Pendidikan Islam

Manajemen teknik Informasi menurut Pratama, merupakan gabungan dari perangkat lunak (software), perangkat keras (hardware) dan sumber daya manusia (SDM) yang saling berkaitan dalam mengolah data menjadi informasi yang bermanfaat melalui penciptaan sebuah sistem. Selain penggunaan komputer, manusia juga turut menjadi bagian dari sistem in. Manusia menggunakan sebuah ide, pemikiran dan perhitungan dalam menggunakan komputer yang di dalamnya terdapat software dan hardware. Selain itu terdapat pula process perencanaan, kontrol, koordinasi dan pengambilan keputusan. Oleh karena itu sistem informasi dinamakan juga sistem kompleks.

Beberapa pendapat ahli tentang pengertian manajemen teknik Informasi sebagaimana dikutip oleh Rochaety sebagai berikut:

a. Gordon B. Davis mengemukakan bahwa manajemen teknik informasi merupakan suatu sistem manusia dan mesin yang terpadu untuk menyajikan informasi guna mendukung fungsi operasi, manajemen, dan proses pengambilan keputusan dalam suatu organisasi.

b. Soetedjo Moeljodiharjo berpendapat bahwa manajemen teknik informasi merupakan suatu metode yang menghasilkan informasi yang tepat waktu yang digunakan untuk langkah pengambilan keputusan dalam rangka memperbaiki perencanaan dan pengendalian

c. Robert W. Holmes mengartikan manajemen teknik informasi sebagai suatu sistem yang dirancang untuk menyajikan informasi pilihan yang berorientasi kepada keputusan guna merencanakan, mengawasi, dan menilai aktivias organisasi yang dirancang dalam kerangka kerja.

d. D. Joseph F. Kelly menyatakan bahwa manajemen teknik informasi merupakan perpaduan antara sumber daya manusia dengan sumber daya lainnya yang berlandaskan komputer sehingga menghasilkan kumpulan penyimpanan, perolehan kembali, 
komunikasi, dan penggunan data untuk tujuan operasi manajemen yang efisien.

Berdasarkan pendapat tersebut dapat ditarik kesimpulan bahwa manajemen teknik informasi dalam pendidikan merupakan rangkaian keterkaitan antara sumber daya manusia dengan aplikasi teknik informasi yang digunakan untuk menyimpan, mengolah, dan mengambil kembali data dalam rangka untuk mendukung proses pengambilan keputusan dalam bidang pendidikan.

2) Tujuan Teknologi Informasi Pendidikan

a. Untuk memecahkan masalah

Dalam memecahkan masalah, teknik informasi juga berperan penting di dalamnya. Pemecahan masalah disini berhubungan tentang semua masalah yang terjadi pada manusia. Peran dari teknik informasi akan sangat vital untuk memecahkan masalah, sebab teknik informasi didalamnya terdapat sebuah informasi yang berguna sebagai pemecah masalah yang terjadi pada kehidupan manusia sehari-hari.

Selain itu teknik informasi sebagai pemecah masalah juga dapat diterapkan pada setiap perusahaan. Setiap perusahaan maupun instansi pemerintahan tidak akan pernah lepas dari suatu masalah. Terutama masalah yang berhubungan dengan pengelolaan manajemen.Jika ditinjau dari kehidupan sehari-hari terjadinya masalah bisa disebabkan dari pihak internal maupun pihak eksternal.Banyak pihak yang menganggap bahwa masalah yang datangnya dari pihak eksternal lebih berbahaya sehingga di prioritaskan untuk segera diselesaikan, sedangkan masalah yang datangnya dari dalam (internal) tidak terlalu berbahaya. Sehingga hal inilah yang dapat membuat suatu perusahaan akan mengalami kebangkutran.

Oleh sebab itu peran teknologi pada suatu instansi sangat berperan penting untuk mengatur perusahaan. Teknik informasi menyangkut tentang teknologi computer, dimana computer sebagai perangkat utama untuk mengolah informasi yang bermanfaat.
Perlu adanya akses internet pada computer agar mendapat informasi yang berkualitas dalam memecahkan masalah, karena pada jaringan internet banyak informasi yang sangat kita perlukan.

\section{b. Untuk membuka kreatifitas.}

Kreativitas sangat diperlukan dalam Teknik informasi dengan beberapa alasan antara lain: pertama, kreativitas memberikan peluang bagi individu untuk mengaktualisasikan dirinya, kedua kreativitas memungkinkan orang dapat menemukan berbagai alternatif dalam pemecahan masalah, ketiga, kreativitas dapat memberikan kepuasan hidup, dan keempat, kreativitas memungkinkan manusia meningkatkan kualitas hidupnya. Dari segi kognitifnya, kreativitas merupakan kemampuan berfikir yang memiliki kelancaran, keluwesan, keaslian, dan perincian.

Sedangkan dari segi afektifnya kreativitas ditandai dengan motivasi yang kuat, rasa ingin tahu, tertarik dengan tugas majemuk, berani menghadapi resiko, tidak mudah putus asa, menghargai keindahan, memiliki rasa humor, selalu ingin mencari pengalaman baru, menghargai diri sendiri dan orang lain, dsb. Karya-karya kreatif ditandai dengan orisinalitas, memiliki nilai, dapat ditransformasikan, dan dapat dipertanggung jawabkan. Contohnya, pembelajaran dengan dukungan Teknik informasi dan telekomunikasi memungkinkan seseorang dapat menghasilkan karya-karya baru yang orsinil, memiliki nilai yang tinggi, dan dapat dikembangkan lebih jauh untuk kepentingan yang lebih bermakna.

Melalui teknik informasi dan telekomunikasi seseorangakan memperoleh berbagai informasi dalam lingkup yang lebih luas dan mendalam sehingga meningkatkan wawasan kita. Hal ini merupakan rangsangan yang kondusif bagi berkembangnya kemandirian terutama dalam hal pengembangan kompetensi, kreativitas, kendali diri, konsistensi, dan komitmennya baik terhadap diri sendiri maupun terhadap pihak lain. Semua hal yang telah dipaparkan di atas tidak akan terjadi dengan sendirinya 
karena setiap orang belajar memiliki kondisi yang berbeda antara satu dengan lainnya. Pengintegrasian teknik informasi dan komunikasi dalam pembelajaran sangat membuka peluang untuk membentuk kreativitas dan kemandirian seseorang. Beragamnya sumber belajar yang dapat diakses membutuhkan kearifan agar selektif dalam memilah dan memilih sumber tersebut. Terbentuknya kreativitas dan kemandirian belajar dalam diri seseorang menjadikan mereka mampu untuk bertahan dan bersaing di era global.nepi dieu

\section{c. Untuk efektif dan efisien}

Tujuan teknik informasi yang efektif dan efisien merupakan hal yang menjadi tujuan utama dalam teknologi informasi. Teknik informasi semacam komputer merupakan sumber dari informasi yang selalu diakses oleh manusia serta semacam perusahaan atau instansi pemerintahan. Teknik informasi dapat dibilang efektif dan efisien sebab teknik informasi dapat diakses dengan mudah dan tidak membutuhkan waktu yang lama. Peranan teknik informasi seperti itu akan berdampak baik untuk kehidupan manusia, seseorang akan mudah mendapatkan semua informasi yang lengkap di seluruh dunia tanpa harus membayar secara mahal.

Tidak hanya manusia yang membutuhkan suatu informasi, perusahaan dan instansi-instansi di dalam pemerintahan pun juga sangat perlu suatu informasi. Perusahaan maupun instansi pemerintah tentunya ingin segera mengetahui apa yang terjadi diluar lingkungan perusahaan atau instansi mereka dengan cepat dan akurat, untuk itu perlu kelengkapan teknik informasi semacam komputer dan koneksi internet agar semua informasi dapat dimiliki. Sebagai contoh dahulu sebelum teknik informasi yang sekarang ini, seseorang dalam membuat suatu tugas atau sedang dalam proses memecahkan masalah sangat sulit dalam proses pengerjaannya, membutuhkan waktu yang lama, dikarenakan teknologi saat itu masih tergolong kurang canggih. Berbeda dengan sekarang ini seseorang akan sangat mudah mengerjakan tugas atau sedang dalam proses pemecahan masalah, sebab teknik informasi saat ini sudah sangat canggih, sehingga apa pun dapat dilakukan dengan efektif dan efisien.

3) Hasil Penerapan Manajemen Teknik Informasi Pendidkan Islam

Teknik informasi sekarang ini berkembang begitu pesatnya sehingga implementasi tekno-logi informasi dan komunikasi beserta komponen infra strukturnya benar-benar telah menandai terjadi-nya revolusi peradaban yang memungkinkan pekerjaan-pekerjaan dalam sistem organisasi dapat di selesaikan secara cepat, akurat, efektif dan efisien. Pemanfaatan sistem informasi manajemen khususnya dalam bidang pendidikan sudah sangat diperlukan dalam pengelolaan, baik dalam hal pengelolaan administrasi akademik, akademik kepegawaian, administrasi pelaporan dan masih banyak lagi bidang-bidang lain yang membutuhkan layanan manajemen teknik informasi Pendidikan. Kebutuhan aplikasi database yang dapat mengelola data dan informasi sekolah, manajemen sekolah dan komite-komite pengajaran dan pembelajaran, juga mengangkat kebutuhan untuk menjadikan laporan-laporan dari sekolah secara cepat dan valid kepada instansi terkait seperti laporan ke Dinas Pendidikan Kabupaten/Kota maupun ke Kementrian Pendidikan Nasional.

Mengingat peran manajemen teknik informasi yang begitu penting sangat diperlukan oleh suatu lembaga/satuan pendidikan. Upaya dan usaha menerapkan IT dalam menunjang kelancaran kinerjanya, dengan kondisi semacam itu seluruh tenaga kependidikan dan pendidik terus melakukan upaya-upaya untuk memperbaiki sistemsistem yang sudah ada. Teknik informasi juga merupakan salah satu senjata pesaing. Hal ini tidak dapat dipungkiri bahwa teknik informasi menjadi salah satu alat untuk meningkatkan efisiensi dalam aktivitas operasional lembaga pendidikan, bahkan untuk menjadi pilihan masyarakat saat ini, lembaga pendidikan harus memiliki sperangkat teknik informasi yang memadai. Dalam rangka 
memberdayakan semua warga negara Indonesia berkembang menjadi manusia yang berkualitas sehingga mampu dan proaktif menjawab tantangan zaman yang selalu berubah. Sebuah komitmen terhadap kualitas pendidikan. Terkait dengan visi tersebut telah ditetapkan serangkaian prinsip penyeleng-garaan pendidikan untuk dijadikan landasan dalam pelaksanaan reformasi pendidikan. Pergeseran paradigma proses pendidikan, yaitu dari paradigma pengajaran ke paradigma pembelajaran. Pembelajaran adalah proses interaksi peserta didik dengan guru dan sumber belajar pada suatu lingkungan belajar. Proses pembelajaran perlu direncanakan, dilaksanakan, agar efektif dan efisien.

Menurut Budi Sutedjo dalam Eti Rochaety bahwa gelombang teknik informasi yang berbasis internet berkembang melalui beberapa tahapan sebagai berikut :

a. Gelombang pertama, pemanfaatan TI difokuskan untuk meningkatkan prouktivitas dan memperkecil biaya.

b. Gelombang kedua, TI difokuskan untuk meningkatkan efektivitas penggunaan peralatan komputer melalui pembangunan jaringan komputer.

c. Gelombang ketiga, TI difokuskan untuk menghasilkan keuntungan melalui pembangunan program sistem informasi.

d. Gelombang keempat, TI difokuskan untuk membantu proses pengambilan keputusan dari data kualitatif.

e. Gelombang kelima, TI difokusakan untuk meraih pelanggan (konsumen) melalui pengembangan jaringan internet.

f. Gelombang keenam, TI mengembangkan sistem jaringan tanpa kabel (wireless). Sistem tersebut dapat memungkinkan seseorang mengakses internet melalui komputer yang terhubung ketelepon seluler.
4) Bidang Manajemen Teknik Informasi Pendidikan

Manajemen teknik informasi merupakan suatu badan yang memiliki bagian-bagian yang memiliki tugas-tugas tertentu. Bagian-bagian itu adalah pengumpulan data, penyimpanan data, pemroses data, dan pemograman data. Dalam bagian-bagian terdapat seseorang coordinator yang bertugas mengkordinir pada semua bagian Dan bertanggung jawab langsung pada manajemen puncak atau kepala sekolah.

\section{a. Bagian Pengumpulan Data}

Bertugas mengumpulkan data, baik bersifat internal maupun eksternal. Data internal merupakan data yang berasal dari dalam organisasi (level manajemen), sedangkan data eksternal merupakan data yang berasal dari luar organisasi namun masih terdapat hubungan demean perkembangan organisasi.

Personalia yang bertugas pada pengumpulan data dapat diambilkan dari seluruh unit kerja dalam organisasi yaitu, wakasek sehingga setiap unit kerja memiliki wakil-wakil untuk menunjang keefektifan pengumpulan data untuk diolah menjadi sebuah informasi yang bermanfaat bagi pengguna informasi.

\section{b. Bagian Penyimpan Data}

Bagian penyimpan data bertugas menyimpan data. Penyimpanan data sangat diperlukan karena tujuan utama adalah demi keamanan data. Apabila level- level manajemen membutuhkan data, baik berupa data bahan mentah maupun data yang telah diolah, maka data dapat diambil dan digunakan sesuai dengan kebutuhan manajer (kepala sekolah maupun wakilnya).

\section{c. Bagian Pengolah Data}

Bagian pengolah data bertugas memproses data dengan mengikuti serangkaian langkah atau pola tertentu sehingga data dirubah ke dalam bentuk informasi yang lebih berguna. Pada pemrosesan data bias dilakukan dilakukan secara manual maupun dengan bantuan 
Uwoh Saepuloh Penerapan Manajemen Teknik Informasi Pendidikan Islam Dalam Proses Pembelajaran Di Smk Harapan 1 Rancaekek Bandung

mesin. Bagian pemrosesan data terdiri dari beberapa ahli yang bertugas membentuk data menjadi informasi yang sesuai dengan kebutuhan level-level manajemen. Karena kebutuhan setiap manajer (kepala sekolah dan wakil kepala sekolah) berbeda, maka kebutuhan data pada tiap-tiap manajer berbeda pula.

\section{d. Bagian Program Data}

Apabila sistem informasi manajemen sudah memiliki perangkat computer, maka bagian pemogram data disebut programmers, yaitu kelompok ahli yang bertanggung jawab atas penyusunan program untuk diberikan kepada perangkat computer. Karena computer memiliki bahasa tersendiri, maka tugas programmer adalah membahasakan data-data yang telah dihimpun sesuai dengan bahasa computer.

\section{Proses Pembelajaran di Sekolah}

Pembelajaran sebagai perpaduan dari dua aktivitas, yaitu aktivitas mengajar dan aktivitas belajar. Aktivitas mengajar menyangkut peranan seorang pendidik dalam konteks mengupayakan terciptanya jalinan komunikasi harmonis atau interaksi edukatif antara mengajar dengan belajar. Jalinan komunikasi yang harmonis inilah yang menjadi indikator suatu aktivitas/proses pembelajaran itu berjalan dengan baik. Pembelajaran adalah totalitas aktivitas belajar mengajar yang diawali dengan perencanaan diakhiri dengan evaluasi .

Pembelajaran adalah operasionalisasi dari kurikulum. Pembelajaran di sekolah terjadi apabila terdapat interaksi antara siswa dengan lingkungan belajar yang diatur oleh pendidik untuk mencapai tujuan pembelajaran

Kaitannya dengan kompetensi sosial pendidik, peserta didik sebagai makhluk sosial dan makhluk etis maka dalam pembelajaran peserta didik diperlakukan secara wajar dan bertujuan agar tercapai optimalisasi potensi pada diri masing-masing peserta didik, memahami dan menerapkan prinsip belajara humanistic yang beranggapan bahwa keberhasilan belajar ditentukan oleh kemampuan yang ada pada diri peserta didik.
Undang-undang tentang Sistem Pendidikan Nasional Nomor 20 Tahun 2003 menyatakan bahwa, pembelajaran adalah proses interaksi peserta didik dengan pendidik dan sumber belajar pada suatu lingkungan belajar. Dalam pembelajaran, pendidik harus memahami hakikat materi pelajaran yang diajarkannya dan memahami berbagai model pembelajaran yang dapat merangsang kemampuan peserta didik untuk belajar dengan perencanaan pengajaran yang matang oleh pendidik.

Berdasarkan defenisi para ahli, dapat disimpulkan bahwa, pembelajaran adalah interaksi peserta didik dengan pendidik dan sumber belajar pada suatu lingkungan belajar yang meliputi pendidik dan peserta didik yang saling bertukar informasi untuk mencapai tujuan pembelajaran. Pendidik sangat berperan dalam membantu perkembangan peserta didik untuk mewujudkan tujuan hidupnya secara optimal. Keyakinan ini muncul karna tidak semua orang tua memiliki kemampuan baik dari segi pengalaman, pengetahuan maupun ketersediaan waktu. Dalam kondisi yang demikian orang tua menyerahkan anaknya kepada pendidik di sekolah dengan harapan agar anaknya dapat berkembang secara optimal.

Pendidik dalam proses pembelajaran, memiliki peran yang sangat penting. Bagaimanapun hebatnya kemajuan sains dan teknologi, peran pendidik tetap diperlukan. Untuk memenuhi tuntutan peranan pendidik, maka pendidik harus mampu memaknai pembelajaran, serta menjadikan pembelajaran sebagai ajang pembentukan kompetensi dan perbaikan kualitas pribadi peserta didik.

Selain pendidik, unsur lain dalam pembelajaran adalah peserta didik, yakni anggota masyarakat yang berusaha mengembangkan potensi pembelajaran pada jalur pendidikan baik pendidikan informal, pendidikan formal maupun pendidikan nonformal, pada jenjang pendidikan dan jenis pendidikan tertentu. Para ahli mendefinisikan peserta didik sebagai orang yang terdaftar dan belajar di suatu lembaga pendidikan tertentu, atau peserta didik merupakan orang yang 
belum dewasa dan memiliki sejumlah potensi yang masih perlu dikembangkan. Sedangkan menurut undang-undang peserta didik adalah anggota masyarakat yang berusaha mengembangkan potensi diri melalui proses pembelajaran yang tersedia pada jalur, jenjang, dan jenis pendidikan tertentu (Undang-Undang Nomor 20 Tahun 2003 Tentang Sistem Pendidikan Nasional).

Dalam proses pendidikan, peserta didik merupakan salah satu komponen manusiawi yang menempati posisi sentral. Peserta didik menjadi pokok persoalan dan tumpuan perhatian dalam semua proses transformasi yang yang disebut pendidikan. Selain pendidik dan peserta didik, unsur lain dalam pembelajaran adalah sumber belajar yakni semua sarana pengajaran yang menyajikan pesan secara edukatif baik visual saja maupun audiovisual, misalnya buku-buku dan bahan cetak lainnya.

taman sekolah dan sebagainya. Sedangkan lingkungan non fisik contohnya AECT (Association of Education and Communication Tecnology) mendefinisikan sumber belajar adalah berbagai atau semua sumber baik yang berupa data, orang dan wujud tertentu yang digunakan oleh peserta didik dalam belajar baik secara terpisah maupun terkombinasi sehingga mempermudah peserta didik dalam mencapai tujuan belajar. Sumber belajar menurut AECT dibedakan menjadi enam jenis yaitu:

1) Pesan (massage), yaitu informasikan yang di transmisikan atau diteruskan oleh komponen lain dalam bentuk ide, ajaran, fakta, makna, nilai, dan data. Contoh: isi bidang studi yang dicantumkan dalam kurikulum pendidikan formal, dan non formal maupun dalam pendidikan informal.

2) Orang (person), yaitu manusia yang berperan sehingga pencari, penyimpan, pengelolah dan penyaji pesan. Contoh: guru, dosen, tutor, siswa, pemain, pembicara, instruktur dan penatar.

3) Bahan (material), yaitu sesuatu wujud tertentu yang mengandung pesan atau ajaran untuk disajikan dengan menggunakan alat atau bahan itu sendiri tanpa alat penunjang apapun. Bahan ini sering disebut media atau sofware atau perangkat lunak. Buku, modul, majalah, bahan pengajaran terprogram, film, video tape, pita audio (kaset audio), dan sebagainya

4) Alat (device), yaitu suatu perangkat yang digunakan untuk menyampaikan pesan yang tersimpan dalam badan. Alat ini disebut hardware atau perangkat keras. Contoh proyektor slide, proyektor film, monitor televisi, monitor komputer, kaset dan lain-lain

5) Teknik (Technique), teknik di artikan sebagai prosedur yang runtut atau acuan yang dipersiapkan untuk menggunakan bahan peralatan, orang dan lingkungan belajar secara kombinasi dan terkoordinasi untuk menyampaikan ajaran atau materi peralatan. Contoh: belajar mandiri, belajar jarak jauh, belajar secara kelompok, simulasi, diskusi, ceramah, problem solving, tanyajawab dan sebagainya.

6) Lingkungan (setting), yaitu situasi disekitar proses belajar mengajar terjadi. Latar atau lingkungan ini dibedakan menjadi dua macam yaitu lingkungan fisik dan non fisik. Lingkungan fisik seperti gedung, sekolah, perpustakaan, laboratorium, rumah, studio, ruang rapat, adalah tatanan ruang belajar, cuaca dan sebagainya.

3. Imlementasi Managemen Teknik Informasi Pendidikan Islam Dalam Pembelajaran Di SMK Harapan 1 Rancaekek Bandung

Managemen Teknik Informasi merupakan, bagian dari ilmu manajemen. Semua fungsi manajemen baik itu perencanaan (planning), pengorganisasian (organizing), pemimpin (leading/actuating), dan pengendalian (contrilling) diperlukan untuk keberhasilan kegiatan dalam suatu organisasi, termasuk dalam bidang pendidikan. Keberhasilan saat menjalankan fungsi manajemen tersebut salah satunya ditunjang oleh sistem informasi yang mampu 
menyediakan informasi yang dibutuhkan para pengolah (pemimpin lembaga tersebut).

Managemen Teknik Informasi adalah suatu sistem yang berorientasi kepada sistem informasi yang mementingkan keakrutan data dan ketepatan sasaran dalam memperoleh berbagai data dan informasi yang dibutuhkan sekolah. Informasi yang dibutuhkan seperti sarana prasarana, pembiayaan, pengelolaan, kompotensi lulusan, penilaian, standar isi, pendidik dan tenaga kependidikan. Adapun sistem pengelola data yang digunakan disini yaitu DAPODIK yang meliputi data pendidik, tenaga kependidikan, data siswa, data sarana dan prasarana, dan sebagainya yang secara cepat dan valid yang disampaikan kepada instansi seperti Dinas Pendidikan kabupaten/kota, maupun ke kementrian nasional.

Untuk melaksanakan Managemen Teknik Informasi di SMK Haraan 1 Rancaekek Bandung mempunyai tiga bagian untuk mengolah data yaitu, bagian pengumpulan data, bagian pengolahan data, dan bagian penyimpanan data.

1) Bagian Pengumpulan Data

Data yang dikumpulkan berupa data internal dan data eksternal. Data internal merupakan data yang berasal dari dalam organisasi sedangkan data eksternal merupakan data yang berasal dari luar organisasi akan tetapi masi terdapat hubungan dengan perkembangan organisasi. Data internal dapat diperoleh dari semua unit kerja dalam organisasi yaitu dari wakasek, meliputi wakasek bagian pengajaran, kesiswaan, sarana prasarana, dan humas. Ini berarti bahwa bidang-bidang fungsional dan berbagai satuan kerja dalam organisasi dapat menjadi sumber data. Sedangkan data eksternal dapat diperoleh dari lingkungan sekitar. pengumpulan data secara eksternal harus disesuaikan demean kondisi dan kebutuhan organisasi.

Jadi, dapat dikatakan bahwa data dapat diperoleh dari berbagai sumber dalam berbagai bentuk. Pada dasarnya data diperoleh pada fakta-fakta yang ada di lapangan. Data yang memiliki makna tertentu bagi pengembangan organisasi, maka data diklarifikasi dan disusun menjadi informasi. Pada pengumpulan data dapat dikatakan berjalan baik dan normal apabila semua komponen di sekolah atau seluruh unit kerja tepat waktu dalam pemberian data dan saling bekerja sama untuk mencapai tujuan organisasi.

\section{2) Bagian Pengolahan Data}

Untuk melakukan pengolahan data tentunya mempunyai prosedur, sebagaimana yang dijelaskan oleh Kepala Sekolah,yang mengatakan:

"Dalam mengolah data dengan mengikuti serangkaian langka tertentu sehingga data diubah ke dalam bentuk informasi yang lebih berguna dengan menggunakan perangkat computer kemudian diinput melalui pengelola data yaitu dapodik. Dengan sistem pengolahan data melalui dapodik maka pengelolaan riwayat data sekolah, peserta didik, pendidik, karyawan sekolah lebih mudah diterintegrasikan dan disimpan secara terpusat dan dapat diakses dengan mudah dalam batasan tertentu melalui internet. Selain itu proses pemutakhiran data dapat dilakukan secara langsung online dan real time dengan memanfaatkan koneksi internet."

Dalam mengolah data dengan prosedur yang telah ditetapkan harus memastikan prosedur tersebut telah terbebas dari kesalahan meliputi:
a. Koneksi peralatan pendukung untuk mengecek pendeteksian kode
b. Memastikan bahwa prosesor yang digunakan tidak terdapat kesalahan
c. Pengecekan terhadap kompatibilitas program sebelumnya dengan program baru yang digunakan
d. Ketersediaan prosedur.

Untuk melakukan pencegahan kesalahan yang terjadi sehingga perlu disediakan prosedur pencegahan yang memberikan informasi tentang prosedur yang 
benar kepada operator dalam pengolahan data.

Dengan demikian bahwa pengolahan data dilakukan secara langsung online dan real time dengan memanfaatkan koneksi internet dan pengolahan data harus dilakukan secara terus menerus dan berkesenambungan di mana unit pengolah data harus mengikuti dan meng-up date data sesuai dengan kenyataan karena hal ini akan mempengaruhi informasi yang diterima manajer (kepala sekolah dan wakil-wakilnya) dan akan berdampak besar pada perkembangan organisasi.

\section{3) Bagian Penyimpanan Data}

Penyimpana data sangat diperlukan, karena tujuan utamanya adalah demi keamanan data. Apabila level-level manajemen membutuhkan data, baik data berupa bahan mentah maupun data yang telah diolah, maka data dapat diambil dan digunakan sesuai dengan kebutuhan manajer (kepala sekolah dan wakil- wakilnya). Penyimpanan informasi sangat penting karena tidak semua informasi yang dimiliki digunakan saat sekarang tetapi sesuai dengan kebutuhan. Menurut kepala sekolah bahwa:

"Untuk menjaga validitas data sekolah, siswa, pendidik dan karyawan, pada sistem dapodik maka diterapkan sistem penomoran khusus yang berfungsi sebagai identitas tunggal yang berlaku seumur hidup dalam skala nasional. Sistem penomoran tersebut menjadi kunci utama Dan demi keamanan data dari sistem dapodik. Maka terdapat tiga subprogram pada dapodik yaitu, NPSN (Nomor Pokok Sekolah Nasional), NISN (Nomor Induk Siswa Nasional), dan NIGN (Nomor Induk Nasional)."

Sedangkan Nomor Induk Guru Nasional (NIGN) adalah kode pengenal guru/karyawan yang berlaku seumur hidup. Penerapan kode pengenal guru/karyawan yang berlaku secara nasional, maka data guru/karyawan pada sistem dapodik terjaga validitasnya. Pada implementasinya, melalui pengolah data dapodik, sekolah diberikan tanggung jawab dalam mengumpulkan data siswa, sekolah, dan guru/karyawan dan mengoperasikan sistem dapodik yang telah disediakan dan melaporkan hasil kerja masing-masing.

Jadi, dapat bahwa informasi yang telah terkumpul dan terolah dengan baik perlu disimpan dengan sebaik mungkin mengingat informasi sebagai salah satu sumber daya strategis dalam organisasi, maka penerapan kode dilakukan agar terjaga validitas data tersebut.

Untuk menjalankan suatu organisasi, tentu diberikan amanah dan tanggung jawab kepada seseorang agar suatu organisasi berjalan sesuai dengan tahapan- tahapan yang sudah direncanakan sebelumnya. Dalam hal ini menurut kepala sekolah menyatakan bahwa:

"Yang bertindak sebagai pelaksana manajemen teknik informasi adalah wakil kepala sekolah yang terdiri dari empat personil seperti Wakasek bagian pengajaran, kesiswaan, sarana dan prasarana, dan humas. Hal yang dibagi misalnya dari kesiswaan yaitu dari seluruh siswa diinput datanya mulai dari data riwayat pendidikan, status keluarga kemudian semua itu dimasukkan dalam sebuah sistem dapodik yang dikoordinir oleh operator sekolah."

Jadi yang bertindak sebagai ketua manajemen teknik informasi adalah kepala sekolah sekaligus penaggung jawab, Dan yang bertindak sebagai pelaksana sistem informasi manajemen adalah wakil kepala sekolah yang terdiri dari empat personil seperti wakasek bagian pengajaran, kesiswaan, sarana prasarana dan humas.

Dalam dunia pendidikan penggunaan dan pengelolaan sistem informasi manajemen pendidikan tidak dapat dipisahkan dari aktivitas pendidikan itu sendiri. Kedua bidang ini saling membutuhkan karena manajemen menilai pendidikan sebagai penggerak pada sistem informasi manajemen pendidikan sekaligus sistem informasi pendidikan sebagai penentu proses manajemen pendidikan.Hal ini 
terjadi di SMK Harapan 1 Rancaekek Bandung bahwa, sistem informasi manajemen sangat berperan dalam dunia pendidikan khususnya dalam proses belajar mengajar di di SMK Harapan 1 Rancaekek Bandung. Sebagaimana yang di jelaskan oleh Kepala Tata Usaha. Berikut penjelasannya:

"Dengan diterapkan sistem informasi manajemen disekolah, dapat dijadikan sebagai salah satu dasar dalam meningkatkan mutu pendidikan dimana dalam memberikan kesempatan kepada guru dan pengurus sekolah untuk meningkatkan kualitas komunikasi dan pembinaan kepada siswa. Siswa juga lebih mengembangkan kepribadian dan pengetahuannya. Misalnya penggunaan teknologi dengan memfasilitasi praktek pembelajaran dengan memadukan computer dengan penggunaan wifi atau jaringan internet. Jadi, ketika dalam proses belajar mengajar akan menciptakan suasana yang efektif, mereka dapat dengn mudah mengerjakan tugas, dalam proses belajar mengajar tidak membosankan, siswa lebih aktif dan semangat belajarnya".

Berdasarkan semua pernyataan informan di atas, maka peneliti dapat menarik kesimpulan bahwa penerapan sistem informasi manajemen pada lembaga pendidikan sangat dibutuhkan, karena dalam menghadapi persaingan global lembaga pendidikan dituntut untuk memberikan informasi lebih cepat, akurat dan nyaman yang merupakan bagian dari kualitas pelayanan, sehingga akan menjadi keunggulan bersaing.

Berikut peneliti memberikan penjelasan mengenai pelaksanaan proses pembelajaran di di SMK Harapan 1 Rancaekek Bandung. Proses pembelajaran merupakan proses interaksi peserta didik dengan pendidik dan sumber belajar pada suatu lingkungan belajar yang meliputi pendidik dan peserta didik yang saling bertukar informasi. Pendidik sangat berperan dalam membantu perkembangan peserta didik untuk mewujudkan tujuan hidupnya secara optimal.

Pendidik dalam proses pembelajaran memiliki peran yang sangat penting bagaimana pun hebatnya kemajuan sains dan teknologi, peran pendidik tetap diperlukan. Untuk melaksanakana proses pembelajaran, mempunyai tiga tahapan dalam proses pembelajaran yaitu: tahapa perencanaan, tahap pelaksana, dan tahap evaluasi.

\section{a. Tahap Perencanaan}

Kegiatan perencanaan yang baik senantiasa berawal dari rencana yang matang. Perencanaan yang matang menunjukkan hasil yang optimal dalam pembelajaran. Perencanaan merupakan proses penyusunan sesuatu yang dilaksanakan untuk mencapai tujuan yang telah ditentukan. Dalam hal ini sebelum melaksanakan proses pembelajaran di di SMK Harapan 1 Rancaekek Bandung, terlebih dahulu harus mempunyai perencanaan/persiapan. yaitu: pertama, Analisis hari efektif dan analisis program pembelajaran. Untuk mengawali kegiatan penyusunan program pembelajaran, guru perlu membuat analisis hari efektif selama selama satu semester. Dari hasil analisis hari efektif diketahui jumlah hari efektif dan hari libur tiap pekan atau tiap bulan sehingga memudahkan penyusunan program pembelajaran selama satu semester.

Dasar pembuatan analisis hari efektif adalah kalender pendidikan dan kalender umum. Berdasarkan analisis hari efektif tersebut dapat disusun analisis program pembelajaran. Kedua, membuat program tahunan, dan program semester. Yang dimaksud dengan program tahunan yaitu, penyusunan program pembelajaran selama tahun pelajaran dimaksudkan agar keutuhan dan kesinambungan program pembelajaran atau topik pembelajaran yang dilaksanakan dalam dua semester tetap terjaga. Program semester yaitu, penyusunan program semester didasarkan pada hasil analisis hari efektif dan program pembelajaran tahunan. Ketiga, Menyusun Silabus. Yang dimaksud dengn silabus yaitu, penjabaran dari standar kompetensi, kompetensi dasar yang ingin 
dicapai, dan pokok-pokok serta uraian materi yang perlu dipelajari siswa dalam rangka mencapai standar kompetensi dan kompetensi dasar.

Keempat, Menyusun Rencana Proses Pembelajaran (RPP). RPP disusun guru sebelum melakukan proses pembelajaran. RPP bersifat khusus dan kondisional, dimana setiap sekolah tidak sama kondisi siswa dan sarana prasarana sumber belajarnya. Karena itu, penyusunan RPP didasarkan pada silabus dan kondisi pembelajaran agar kegiatan pembelajaran dapat berlangsung sesuai harapan. Kelima, Penilaian Pembelajaran. Yang dimaksud penilaian pembelajaran yaitu, proses yang harus dilakukan guru dalam rangkaian kegiatan pembelajaran. Prinsip penilaian antara lain valid, mendidik berorientasi pada kompetensi, adil, objektif, terbuka, dan berkesenambungan."

Jadi, sebelum melaksanakan proses pembelajaran terlebih dahulu menyiapkan segala sesuatu yang diperlukan dalam proses pembelajaran seperti, menganalisis hari efektif dan analisis program pembelajaran, membuat program tahunan dan program semester, menyusun silabus, menyusun RPP, dan membuat penilaian pembelajaran. Kemudian sebelum menyampaikan materi/informasi terlebih dahulu menyampaikan tujuan pembelajan dan indikator- indikator pembelajaran yang akan dicapai.

\section{b. Tahap Pelaksanaan}

Tahap ini merupakan tahap implementasi atau tahap perencanaan atas desain perencanaan yang telah dibuat guru. Dalam tahap ini, guru melakukan interaksi belajar mengajar melalui penerapan berbagai strategi metode dan teknik pembelajaran, serta pemanfaatan seperangkat media. Dalam tahap pelaksanaan pembelajaran ada beberapa hal yang perlu diperhatikan guru yaitu, pertama, Aspek Pendekatan dalam Pembelajaran. Pendekatan ini berupa pendekatan pembelajaran pemrosesan informasi, yaitu membantu siswa untuk memproses informasi yang diperoleh pendekatan pembelajaran individu yaitu, membantu siswa mengembangkan pribadi agar lebih produktif terhadap situasi dan lingkungan.

Kedua, Aspek Strategi dan Taktik dalam Pembelajaran. Strategi pembelajaran yaitu, tindakan pembelajaran yang dilakukan guru yang dinilai strategis untuk mengaktualisasikan proses pembelajaran. Terkait dengan pelaksanaan strategi adalah taktik pembelajaran. Taktik pembelajaran berhungan dengan tindakan teknis untuk menjalankan strategi. Untuk melaksanakan strategi diperlukan kiat-kiat teknis, agar nilai strategis setiap aktivitas yang dilakukan guru, murid di kelas dapat terealissi. Ketiga, Aspek Metode dan Teknik dalam Pembelajaran. Metode merupakan bagian dari sejumlah tindakan strategis yang menyangkut tentang cara, bagaimana interaksi pembelajaran dilakukan. Metode yang digunakan dalam proses pembelajaran yaitu, metode ceramah, berdiskusi, bekerja kelompok, bersimulasi, dan sebagainya. Dan media pembelajaran yang digunakan yaitu, media cetak (buku), gambar, LCD dan komputer.

Untuk mengembangkan potensi peserta didik, peserta didik membuat kelompok belajar yang diarahkan langsung oleh guru mata pelajaran dengan menggunakan media pembelajaran berupa computer dan LCD, peserta didik mencari materi yang mereka butuhkan kemudian mendiskusikannya atau memecahkan masalah yang tidak dipahami dengan teman kelompok lainnya.Pendidik juga harus mampu memahami dan memberikan solusi atas segala kesulitan yang dihadapi peserta didik dalam proses pembelajaran.

Jadi dapat disimpulkan bahwa dalam tahap pelaksanaan proses pembelajaran yaitu, menggunakan aspek pendekatan, menggunakan aspek strategi dan taktik dalam proses pembelajaran, menggunakan metode dan teknik dalam proses pembelajaran. Metode yang digunakan dalam proses pembelajaran yaitu, ceramah, berdiskusi, berkelompok, bersimulasi, dan sebagainya. Media yang digunakan dalam proses 
pembelajaran yaitu, media cetak (buku), gambar, LCD, dan komputer.

\section{c. Tahap Evaluasi}

Pada tahap evaluasi, kegiatan guru adalah melakukan penilaian atas proses pembelajaran yang telah dilakukan. Evaluasi adalah alat untuk mengukur ketercapaian tujuan. Dengan evaluasi, dapat diukur kuantitas dan kualitas pencapaian tujuan pembelajaran. Evaluasi pengetahuan belajar dapat dilakukan dengan ujian tulis, lisan, dan daftar ujian pertanyaan. Evaluasi belajar keterampilan, dapat dilakukan dengan ujian praktek, analisis keterampilan dan analisis tugas serta evaluasi oleh peserta didik sendiri. Evaluasi belajar sikap dapat dilakukan dengan daftar sikap isian, daftar isian sikap yang disesuaikan dengan tujuan program, dan skala deferensial sematik.

Jadi dalam melaksanakan tahap evaluasi, yang perlu dievaluasi oleh pendidik yaitu, pengetahuan belajar yang dites dengan secara tertulis, lisan, dan daftar pertanyaan ujian. Evaluasi belajar keterampilan yang dievaluasi dengan ujian praktek, dan analisis tugas yang dievaluasi sendiri oleh pendidik. Dan bentuk tes yang diberikan kepada peserta didik tetap harus dengan persyaratan yang baku. Keberadaan teknik informasi sangat membantu dalam pelaksanaan proses belajar mengajar. Mempermudah pendidik dalam menyampaikan informasi, dan mempermudah dalam mencari bahan ajar.

\section{PENUTUP}

Berdasarkan data-data yang dikumpulkan dan dijelaskan pada bagian sebelumnya peneliti dapat memperoleh kesimpulan sebagai berikut:

Managemen
merupakan, bagian $\begin{array}{r}\text { Informasi } \\ \text { dari ilmu }\end{array}$ manajemen. Semua fungsi manajemen baik itu perencanaan (planning), pengorganisasian (organizing), pemimpin (leading/actuating), dan pengendalian (contrilling) diperlukan untuk keberhasilan kegiatan dalam suatu organisasi, termasuk dalam bidang pendidikan. Penerapan sistem informasi manajemen sangat penting dilembaga pendidikan khusunya di SMK Harapan 1 Rancaekek Bandung. Di mana menggunakan aplikasi pengolah data yaitu dapodik dan teknik informasi dalam mendukug proses pembelajaran memberikan layanan pendidikan dengan menfasilitasi praktek pembelajaran dengan menggunakan infrakstruktur teknologi, seperti fasilitas belajar dengan memadukan komputer.

2. Proses pembelajaran di SMK Harapan 1 rancaekek Bandung berdasarkan hasil penelitian yaitu, sebelum melaksanakan proses pembelajaran harus melalui tiga tahap yaitu, pertama, tahap perencanaan. Dalam tahap ini membuat analisis hari efektif dan analisis program pembelajaran, membuat program tahunan, menyusun silabus, menyusun RPP, dan membuat penilaian pembelajaran. Kedua, tahap pelaksanaan. Dalam tahap ini yang perlu dilakukan yaitu, Aspek pendekatan dalam pembelajaran, Aspek stretegi dan taktik dalam pembelajaran, Aspek metode dan teknik dalam pembelajaran. Media pembelajaran yang dipakai dalam proses pembelajaran yaitu, media cetak (buku), gambar, LCD dan computer. Ketiga, tahap evaluasi. Dalam tahap ini yang dievaluasi yaitu, pengetahuan belajar yang dites dengan secara tertulis, lisan, dan daftar pertanyaan ujian. Evaluasi belajar keterampilan yang dievaluasi dengan ujian praktek, dan analisis tugas yang dievaluasi sendiri oleh pendidik. Dan bentuk tes yang diberikan kepada peserta didik tetap harus dengan persyaratan yang baku.

\section{DAFTAR PUSTAKA}
Dwi Nugroho Hidayanto, Pemikiran Pendidikan dari Filsafat ke Ruang Kelas Cet. III; Samarinda: Spirit Grafindo, 2011

G Sudjarwo, Beberapa Aspek Pengembangan Sumber Belajar, Jakarta: PT Mediatama Sarana Perkasa, 2009, 
Uwoh Saepuloh Penerapan Manajemen Teknik Informasi Pendidikan Islam Dalam Proses Pembelajaran Di Smk Harapan 1 Rancaekek Bandung

Helmawati. Sistem Informasi Manajemen, Bandung: PT Remaja Rosdakarya Offset, 2015

Kenneth Promozic, Online; http://www.jsofian.wordpress.com /2009/05/06/tahapan-gelombanginovasi.

Kumurotomo Wahyudi, Sistem Informasi Manajemen, Yogyakarta: Gaja Mada University Press, 2009.

Pute Agus Eka Pratama, Sistem Informasi dan Implementasinya: Teori dan Konsep Sistem Informasi Disertai Berbagai Contoh Praktiknya Munggunakan Perangkat Lunak Open Source, Bandung: Informatia, 2014.
Rochaety Eti, Sistem Informasi Manajemen, Jakarta: Mitra Wacana Media, 2011

Soeharto Karti, Teknologi Pembelajaran Pendekatan Sistem, Konsepsi dan odel SAP, Evaluasi Sumber Belajar dan Media, Surabaya: SIC 2003.

Sudjana Nana, Teknologi Pengajaran, Bandung: Sinar Baru, 2009

Sutabri Tata, Sistem Informasi Manajemen. Yogyakarta: Andi, 2005.

Uno B. Hamzah, Perencanaan Pembelajaran. Jakarta: PT Bumi Aksara, 2009

Yasin Salehuddin, pengelolaan Pembelajaran, Makassar: Alauddin Press 2010. 